\section{EFIKASNOST KINEZI TRAKA U PREVENCIJI I REHABILITACIJI SPORTSKIH POVREDA}

\section{EFFICIENCY OF KINESIO TAPING IN PREVENTION AND REHABILITATION OF SPORT INJURIES}

SAŽETAK

Kinezi trake se sve više koriste u sportskoj fizioterapiji $i$ posturalnoj rehabilitaciji. Mnogi profesionalni sportisti koriste trake kako bi podržali povređene, izmorene ili prekomerno iskorišćene mišiće. Konstrukcija trake je jedinstvena, ona poseduje visoko elastična svojstva koja angažuju $i$ mišiće $i$ fasciju. Veruje se da KT podržava povređene mišiće i zglobove kao i da oslobađa od bola tako što podiže kožu dozvoljavajući krvni $i$ limfni protok. Cilj ovog preglednog članka je da evaluira, koristeći meta-analizu, efikasnost KT u tretmanu i prevenciji sportskih povreda. Elektronske baze podataka, poput SPORTDiscus, Scopus, MEDLINE, ScienceDirect $i$ sajtovi sportske medicine su pretraživani koristeći ključne reči 'kinezi tejping/trake'. Efikasnost KT u oslobađanju od bola bila je beznalajna s obzirom da nije bilo klinički važnih rezultata. Što se tiče opsega pokreta, dobijeni su neusaglašeni rezultati sa malim korisnim rezultatima, zapaženim $u$ dve studije, mada beznačajni rezultati u druge dve studije za brojne zglobove. Ostvaren je koristan efekat za propriocepciju po pitanju osećaja za grešku u testu sile stiska šake, mađutim, nije bilo pozitivnih efekata za propriocepciju skočnog zgloba. KT su ostvarile znatan efekat na mišićnu aktivnost, mada nije jasno da li su te promene bile korisne ili štetne. Da zaključimo, postoji jako malo kvalitetnih dokaza koji bi podržali korišćenje KT, u poređenju sa drugim tipovima elestičnih traka, u upravljanju ili prevenciji sportskih povreda. KT mogu imati malu korisnu ulogu u poboljšanju sile, opsega pokreta kod određenih povređenih subjekata, kao i u poboljšanju osećaja za grešku, u poređenju sa drugim trakama, mada potrebna su dalja istraživanja koja bi to potvrdila.

Ključne reči: sportska medicina, kineziterapija, oporavak, atrofija
Bojan Ilić ${ }^{1}$, Aleksandra

Nikolić $^{2}$ i Dejan Ilić ${ }^{1}$

${ }^{1}$ Obrazovni sistem Ruđer Bošković, Beograd, Srbija

${ }^{2}$ Fakultet sporta i fizičkog vaspitanja, Univerzitet u Beogradu, Srbija

Pregledni članak doi:10.5550/sgia.171301.se.INI

UDK: 796:615.8 COBISS.RS-ID 6760472 Primljeno: 04.05.2017. Odobreno: 21.06.2017.

Korespodencija:

Prof. dr Dejan Ilić

Fakultet sporta i fizičkog vaspitanja

Univerzitet $\mathrm{u}$ Beogradu

Blagoja Parovića 156

11030 Beograd

Srbija

Tel:+381(11)3531-000

dejan.ilic@,fsfv.bg.ac.rs

Sportlogia 2017, 13 (1), 53-67.

E-ISSN 1986-6119

Ilić, B., et al: Efikasnost kinezi traka...Sportlogia 2017, 13 (1), 53- 67. Stranica 53. 


\section{UVOD}

Tejpiranje se široko koristi u prevenciji povreda kod sportista (Thelen, Dauber i Stonerman, 2008). Kinezi traka (KT), koju je izmislio Kenzo Kase 1996-te godine, predstavlja novi vid primene lepljive trake (Liu, Chen, Lin, Huang i Sun, 2007). Veruje se da KT podržava povređene mišiće i zglobove, kao i da smanjuje bol tako što odiže kožu čime se olakšava protok krvi i limfe (Kahanov, 2007). Traka se koristi za lečenje skoro svega, od glavobolje pa to problema sa stopalima i svega između. Primeri uključuju rehabilitaciju od sportskih povreda, zatim od karpalnog sindroma, bola u donjem delu leđa (subluksacije, hernije diskova), kao i od bolnih stanja kolena i ramena, ali i mnoge druge (Lim, Park i Bae, 2013).

Prema upustvu o korišćenju KT (Kase i Wallis, 2002) zapaža se da su one veoma rastegljive (čak do $75 \%$ od svoje prvobitne dužine), kao i to da je njihov mehanizam rada zasnovan na pravcu lepljenja i napetosti. Kase je opisao tehniku primene KT i za „mišićnu facilitaciju” kao i za „mišićnu inhibiciju”. Primena KT od početnog pripoja mišića do njegove insercije, sa većom tenzijom, tj. sa istezanjem trake za 50-75\% od njene prvobitne dužine, može povećati mišićnu kontrakciju (Kase, K., Wallis i Kase, T. 2003). Suprotno tome, mišićna kontrakcija se može smanjiti ukoliko se KT postavi od mišićne insercije do njegovom početnog pripoja sa slabijom tenzijom, tj. sa $15-25 \%$ od prvobitne dužine trake (Kase, K., Wallis i Kase, T. 2003).

Korisni efekti KT podrazumevaju facilitaciju propriocepcije (Halseth, McChesney, DeBeliso, Vaughn, i Lien, 2004; Jaraczewska i Long, 2006; Riemann i Lephart, 2002), zatim mišićnu facilitaciju (Hammer, 2006), smanjenje umora mišića, smanjenje odloženog početka mišićnog umora (Nosaka, 1999), inhibiciju bola (Kahanov, 2007; Kneeshaw, 2002), pospešenje procesa izlečenja tako što utiče na smanjenje edema i poboljšanje limfne drenaže i krvnog protoka (Kase, Hashimoto i Tomoki, 1998; Kinesio Holding Corporation, 2008; Lipinska, Sliwinski, Kiebzak, Senderek i Kirenko, 2007; Zajt-Kwiatkowska, Rajkowska-Labon, Skrobot, Bakula i Szamotulska, 2007). Štaviše, dr Kenzo Kase je tvrdio da je jedan od efekata KT da povećaju mišićnu silu (Kase, K., Wallis i Kase, T. 2003). KT mogu povećati mišićnu aktivnost tako što povlače fasciju, ukoliko se apliciraju od početnog pripoja mišića do njegove insercije (Hammer, 2006). KT se mogu primeniti gotovo na svaki mišić ili zglob u ljudskom telu. Međutim, ne postoji dovoljno dokaza koji bi podržali upotrebu KT u tretmanu i rehabilitaciji nakon povrede. Ograničen broj studija koje su se bavile ispitivanjem upotrebe KT pokazuju da se KT mogu koristiti zarad poboljšanja funkcija ljudske lokomocije. Pored toga, KT mogu pomoći pri otklanjanju bolova čime se poboljšava stabilnost i propriocepcija kod pacijenata sa akutnom dislokacijom patele, zatim kod pacijenata koji su pretrpeli moždani udar, kao u u stanjima gde pacijenti pate od bolova u zglobovima i disfunkcije trupa.

Ove informacije dolaze iz serije studija i malih pilot studija i time predstavljaju niže nivoe kliničkih dokaza. Pretpostavlja se da KT mogu biti korisno sredstvo u rehabiliatciji i tretmanu povređenih sportista, mada ne postoji dovoljno studija koje bi potvrdile ove iskaze.

Ilić, B., et al: Efikasnost kinezi traka...Sportlogia 2017, 13 (1), 53- 67. Stranica 54. 


\section{METODE}

Cochrane Collaboration pregled metodologije (proučavanje literature, procena kvaliteta istraživanja, prikupljanje podataka karakteristika istraživanja, analiza i interpretacija rezultata, preporuke za kliničke prakse i dalja istraživanja) je korišćen za procenu efikasnosti KT u tretmanu i sprečavanju sportskih povreda.

Elektronske baze podataka koje podrazumevaju SPORTDiscus, Scopus, MEDLINE, ScienceDirect i medicinski veb sajtovi su pretraživani korićenjem ključne reči 'kinezi tejping/trake'. Od 96 nađenih radova, 10 je korišćeno u meta-analizi pomoću kriterijuma uključenja/isključenja: (i) radovi koji sadrži podatke o efektu KT na mišićno-skeletni ishod (pr. bol, opseg pokreta, propriocepcija); (ii) radovi koji su sadržali KT grupu i grupu koja se poredila (pr. KT koje se koriste bez napona, placebo trake, bez trake) i (iii) cela verzija je bila dostupna na engleskom jeziku.

Kvalitet 10 radova koji su odgovarali odabranom kriterijumu uključivanja/isključivanja je ocenjen na osnovu sledećih ključnih komponenata metodološkog kvaliteta: slučajnom raspodelom subjekata, zaslepljivanjem subjekata i zaslepljivanjem svih procenitelja. Ovi kriterijumi su definisani kao fundamentalni u smanjivanju predrasuda u kliničkim ispitivanjima. Za 10 podrazumevanih istraživanja, podaci su ekstrahovani uključujući karakteristike učesnika, dizajn istraživanja, metodološki kvalitet, intervencije, ishod merenja i rezultate.

Brojni rezultati merenja su korišćeni u proceni ekikasnosti KT, uključujući snagu, bol, opseg kretanja, propriocepciju i aktivnost mišića. Analizirani su svi statistički značajni rezultati zabeleženi unutar 10 istraživanja i napravljeni klinički zaključci po pitanju istinite vrednosti njihove efikasnosti na način opisan od strane Batterham-a i Hopkins-a. Takođe su procenjeni i rezultati koji nisu zabeleženi kao statistički značajni (gde je bilo dovoljno podataka), i bilo koji rezultati koji su mogli biti od koristi u analizi su diskutovani unutar tematskog dela.

\section{REZULTATI}

Pregled detalja 10 istraživanja meta-analize su sumirani u tabeli I. Tabele II i III rezimiraju statistički pozitivne rezultate KT i naše tumačenje veličine efekata i njihov klinički značaj. Osam istraživanja je zabeležilo statistički značajan pozitivan ishod za najmanje jedan ishod mere. 
Tabela I. Karakteristike studija koje su proučavale uticaj kinezi traka na smanjenje bola $i$ povećanje sile, opsega pokreta, propriocepcije i mišićne aktivnosti

\begin{tabular}{|c|c|c|c|c|}
\hline Studija & $\begin{array}{l}\text { Kvalitet } \\
\text { studije }\end{array}$ & Cilj studije & Dizajn studije & $\begin{array}{c}\text { Karakteristike } \\
\text { ispitanika }\end{array}$ \\
\hline $\begin{array}{l}\text { Thelen, Dauber i } \\
\text { Stonerman, } 2008\end{array}$ & 4 & $\begin{array}{l}\text { Efekat KT naspram korišćenja } \\
\text { lažne trake }\end{array}$ & $\begin{array}{l}\text { Randomizirana, slepa } \\
\text { studija }\end{array}$ & $\begin{array}{l}\text { Kontrolna grupa: } \\
20 \pm 2 \text { god., } 17 \mathrm{M} \text { i } 4 \text { Ž. } \\
\text { Svim pacijentima je } \\
\text { klinički } \\
\text { dijagnostikovan } \\
\text { tendinitis rotatorne } \\
\text { manžete/ } \\
\text { impingement sindrom }\end{array}$ \\
\hline $\begin{array}{l}\text { GonzaLez-Iglesias et } \\
\text { al., } 2009\end{array}$ & 4 & $\begin{array}{l}\text { Efekat KT naspram korišćenja } \\
\text { lažne trake za tretman bola u vratu } \\
\text { i opseg pokreta u cervikalnom delu } \\
\text { nakon povrede ovog dela kičme }\end{array}$ & $\begin{array}{l}\text { Randomizirana, slepa } \\
\text { klinička studija }\end{array}$ & $\begin{array}{l}\text { Kontrolna grupa: } \\
32 \pm 7 \text { god., } 10 \mathrm{M} \mathrm{i} 10 \\
\text { Ž. Eksperimentalna } \\
\text { grupa: } 33 \pm 6 \text { god., } 10 \\
\mathrm{M} \text { i } 11 \mathrm{~F} \text {. svi pacijenti } \\
\text { su se žalili na bol u } \\
\text { vratu nakon } \\
\text { saobraćajne nesreće } \\
\text { na motoru. }\end{array}$ \\
\hline Hsu et al., 2009 & 3 & $\begin{array}{l}\text { Efekat KT naspram lažne trake na } \\
\text { kinematiku, mišićnu aktivnost i } \\
\text { silu skapularnog regiona kod } \\
\text { bejzbol igrača sa impingement } \\
\text { sindromom }\end{array}$ & $\begin{array}{l}\text { Presečno } \\
\text { randomizirano } \\
\text { istraživanje sa pre- } \mathrm{i} \\
\text { post-test merenjima. } \\
\text { Ispitanici su } \\
\text { zaslepljeni. }\end{array}$ & $\begin{array}{l}17 \text { amaterskih bejzbol } \\
\text { igrača sa impingement } \\
\text { sindromom }\end{array}$ \\
\hline Chang et al., 2010 & 3 & $\begin{array}{l}\text { Efekat KT naspram placebo i ne } \\
\text { korišćenja trake na maksimalnu } \\
\text { jačinu stiska šake kod zdravih } \\
\text { studenata koji se bave sportom } \\
\text { Efekat KT naspram placebo i ne }\end{array}$ & $\begin{array}{l}\text { Randomizirana, slepa } \\
\text { studija sa ponovljenim } \\
\text { merenjima i jednom } \\
\text { grupom }\end{array}$ & $\begin{array}{l}21 \text { zdravih studenata } \\
\text { koji su se bavili } \\
\text { sportom: } 21 \pm 3 \text { god. }\end{array}$ \\
\hline Vithoulka et al., 2010 & 2 & $\begin{array}{l}\text { korišćenja trake na jačinu } m \text {. } \\
\text { quadriceps-a pri maksimalnim } \\
\text { koncentričnim i ekscentričnim } \\
\text { izokinetičkim vežbama }\end{array}$ & $\begin{array}{l}\text { Randomizirana } \\
\text { studija, ponovljena } \\
\text { merenja }\end{array}$ & $\begin{array}{l}20 \text { zdravih ispitanica } \\
\text { koje se ne bave } \\
\text { sportom. } \check{Z}: 27 \pm 4 \text { god. }\end{array}$ \\
\hline $\begin{array}{l}\text { Yoshida i Kahanov, } \\
2007\end{array}$ & 2 & $\begin{array}{l}\text { Efekat KT naspram ne korišćenja } \\
\text { traka na fleksiju, lateralnu fleksiju } \\
\text { i ekstanziju trupa }\end{array}$ & $\begin{array}{l}\text { Randomizirana } \\
\text { presečna pre- i post- } \\
\text { test studija } \\
\text { ponovljenih merenja }\end{array}$ & $\begin{array}{l}30 \text { zdravih ispitanika: } \\
27 \pm 6 \text { god.; } 15 \mathrm{M} \text { i } 15 \\
\breve{Z}\end{array}$ \\
\hline Fu et al., 2008 & 2 & $\begin{array}{l}\text { Efekat KT naspram ne korišćenja } \\
\text { traka na mišićnu jačinu } m \text {. } \\
\text { quadriceps-a i zadnje lože buta }\end{array}$ & $\begin{array}{l}\text { Mišićna sila je bila } \\
\text { procenjena u tri stanja } \\
\text { (bez KT, odmah } \\
\text { nakon aplikacije KT i } \\
\text { 12h nakon stavljanja } \\
\text { trake in situ). } \\
\text { Randomiziran red tri } \\
\text { stanja }\end{array}$ & $\begin{array}{l}14 \text { zdravih studenata } \\
\text { koji se bave sportom: } \\
20 \pm 1 \text { god.; } 7 \mathrm{M} \text { i } 7 \mathrm{Z}\end{array}$ \\
\hline Halseth et al., 2004 & 2 & $\begin{array}{l}\text { Efekat KT naspram ne korišćenja } \\
\text { trake na propriocepciju skočnog } \\
\text { zgloba (tj. na smanjenje osećaja za } \\
\text { poziciju zgloba). }\end{array}$ & $\begin{array}{l}\text { Randomizirana studija } \\
\text { sa ponovljenim } \\
\text { merenjem }\end{array}$ & $\begin{array}{l}30 \text { zdravih ispitanika: } \\
18-30 \text { go.; } 15 \mathrm{M} \text { i } 15 \\
\breve{Z}\end{array}$ \\
\hline $\begin{array}{l}\text { Lee, Yoo and Lee, } \\
2010\end{array}$ & 2 & $\begin{array}{l}\text { Efekat KT naspram ne korišćenja } \\
\text { trake na silu stiska šake }\end{array}$ & $\begin{array}{l}\text { Randomizirana studija } \\
\text { sa ponovljenim } \\
\text { merenjem }\end{array}$ & $\begin{array}{l}40 \text { zdravih ispitanika: } \\
23 \pm 2 \text { god.; } 20 \mathrm{M} \text { i } 20 \\
\breve{Z}\end{array}$ \\
\hline Slupik et al., 2007 & 1 & $\begin{array}{l}\text { Efekat KT naspram ne korišćenja } \\
\text { trake na bioelektričnu aktivnost } m \text {. } \\
\text { vastus medialis-a }\end{array}$ & $\begin{array}{l}\text { Nerandomizirano } \\
\text { kontrolno ispitivanje }\end{array}$ & $\begin{array}{l}27 \text { zdravih ispitanika: } \\
23 \pm 4 \text { god.; } 15 \mathrm{M} \text { i } 12 \\
\breve{Z}\end{array}$ \\
\hline
\end{tabular}

a Kvalitet studije je ocenjivan od 1 do 4 pri čemu veći broj ukazuje na bolji kvalitet: 4 = kontrolna eksperimentalna studija sa randomiziranom raspodelom ispitanika, i sa zaslepljivanjem ispitanika i procenjivača; $3=$ kontrolna eksperimentalna studija sa randomiziranom raspodelom ispitanika, i sa zaslepljivanjem ispitanika, ali ne i procenjivača; $2=$ kontrolisana eksperimentalna

Ilić, B., et al: Efikasnost kinezi traka...Sportlogia 2017, 13 (1), 53- 67. Stranica 56. 
studija sa randomiziranom raspodelom ispitanika, ali bez zaslepljivanja ispitanika i procenjivača; $1=$ kontrolisana eksperimentalna studija bez randomizirane raspodele ispitanika, i bez zaslepljivanja ispitanika i procenjivača.

b Podaci o uzrastu ispitanika predstavljeni su kao srednja \pm standardna devijacija.

$\check{\mathbf{Z}}=$ žene; $\mathbf{M}=$ muškarci.

Tabela II. Rezultati o efikasnosti primene KT na povećanje opsega pokreta

\begin{tabular}{|c|c|c|c|c|}
\hline Studija & Merena varijabla & Komparacija tretmana & Pozitivni ishodi & $\begin{array}{l}\text { Najmanje beneficijaln } \\
\text { razlike }\end{array}$ \\
\hline $\begin{array}{l}\text { Thelen, Dauber i } \\
\text { Stonerman, } 2008\end{array}$ & $\mathrm{ROM}$ & $\begin{array}{c}\text { KT naspram placebo } \\
\text { tretmana }\end{array}$ & $\begin{array}{l}19.1 \pm 10.8^{\circ} \text { (bezbola } \\
\text { abdukcija u zglobu } \\
\text { ramena; } 1 \text { dan) }\end{array}$ & Povećanje od $15^{\circ}$ \\
\hline \multirow[t]{11}{*}{$\begin{array}{l}\text { GonzaLez-Iglesias } \\
\text { et al., } 2009\end{array}$} & $\mathrm{ROM}$ & $\begin{array}{c}\text { KT naspram placebo } \\
\text { tretmana }\end{array}$ & $\begin{array}{l}6.6 \pm 1.1^{\circ} \text { cerv. } \\
\text { fleksija }\end{array}$ & Povećanje od $9.6^{\circ}$ \\
\hline & & & $\begin{array}{l}7.4 \pm 1.8^{\circ} \text { (cerv. } \\
\text { fleksija } 24 \mathrm{~h})\end{array}$ & Povećanje od $9.6^{\circ}$ \\
\hline & & & $\begin{array}{l}8.2 . \pm 1.7^{\circ} \text { (cerv. } \\
\text { ekstenzija) }\end{array}$ & Povećanje od $7.0^{\circ}$ \\
\hline & & & $\begin{array}{l}8.5 \pm 2.0^{\circ}(\text { cerv. } \\
\text { ekstenzija } 24 \mathrm{~h}) \\
5.4 \pm 1.3^{\circ}(\text { desna }\end{array}$ & Povećanje od $7.0^{\circ}$ \\
\hline & & & $\begin{array}{l}\text { lateralna fleksija u } \\
\text { cerv. delu) }\end{array}$ & Povećanje od $5.9^{\circ}$ \\
\hline & & & $\begin{array}{l}5.8 \pm 1.5^{\circ} \text { (desna } \\
\text { lateralna fleksija u } \\
\text { cerv. delu) }\end{array}$ & Povećanje od $5.9^{\circ}$ \\
\hline & & & $\begin{array}{c}3.1 \pm 1.9^{\circ} \text { (leva } \\
\text { lateralna fleksija u } \\
\text { cerv. delu) }\end{array}$ & Povećanje od $9.1^{\circ}$ \\
\hline & & & $\begin{array}{c}2.3 \pm 1.9^{\circ} \text { (leva } \\
\text { lateralna fleksija } \\
24 \mathrm{~h})\end{array}$ & Povećanje od $9.1^{\circ}$ \\
\hline & & & $\begin{array}{c}5.5 \pm 1.5^{\circ}(\text { desna } \\
\text { rotacija u cerv. delu })\end{array}$ & Povećanje od $7.6^{\circ}$ \\
\hline & & & $\begin{array}{c}6.1 \pm 1.8^{\circ}(\text { desna } \\
\text { rotacija u cerv. delu })\end{array}$ & Povećanje od $7.6^{\circ}$ \\
\hline & & \multirow{4}{*}{$\begin{array}{c}\text { KT naspram placebo } \\
\text { tretmana }\end{array}$} & $\begin{array}{c}5.2 \pm 1.4^{\circ} \text { (leva } \\
\text { rotacija u cerv. delu) }\end{array}$ & Povećanje od $6.7^{\circ}$ \\
\hline \multirow{3}{*}{ Hsu et al., 2009} & \multirow{3}{*}{$\mathrm{ROM}$} & & $\begin{array}{l}4.1 \pm 1.5^{\circ} \text { (leva cerv. } \\
\text { rotacija) }\end{array}$ & Povećanje od $6.7^{\circ}$ \\
\hline & & & $\begin{array}{c}1.1 \pm 0.7^{\circ} \text { (posteriorni } \\
\text { tilt pri elevaciji } \\
\text { humerusa od } 30^{\circ} \text { ) }\end{array}$ & Povećanje od $1.2^{\circ}$ \\
\hline & & & $\begin{array}{l}1.2 \pm 0.8^{\circ} \text { (posteriorni } \\
\text { tilt pri elevaciji }\end{array}$ & Povećanje od $1.2^{\circ}$ \\
\hline
\end{tabular}

Ilić, B., et al: Efikasnost kinezi traka...Sportlogia 2017, 13 (1), 53- 67. Stranica 57. 
Yoshida i Kahanov, 2007
$\mathrm{ROM}$
KT naspram ne korišćenja

trake
$17.8 \pm 14.8 \mathrm{~cm}$ (fleksija trupa)
$6.37 \mathrm{~cm}(10 \%$ povećanje bez trake)

$\mathbf{K T}=$ kinezi trake; $\mathbf{R O M}=$ opseg pokreta; Cerv. $=$ cervikalni deo kičme

Tabela III. Rezultati o efikasnosti primene KT na smanjenje bola, povećanje propriocepcije, sile i mišićne aktivnosti

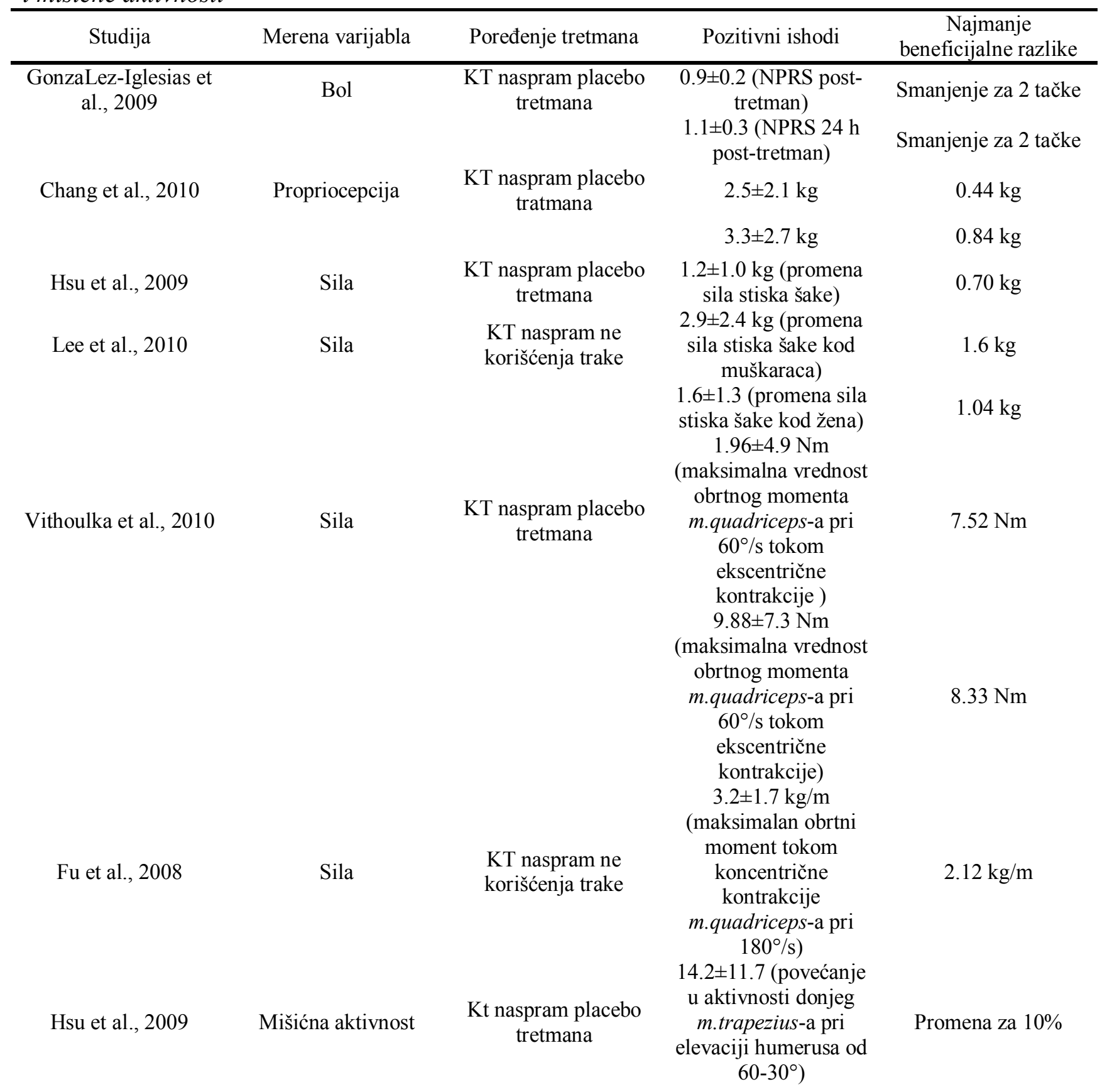

Ilić, B., et al: Efikasnost kinezi traka...Sportlogia 2017, 13 (1), 53- 67. Stranica 58. 


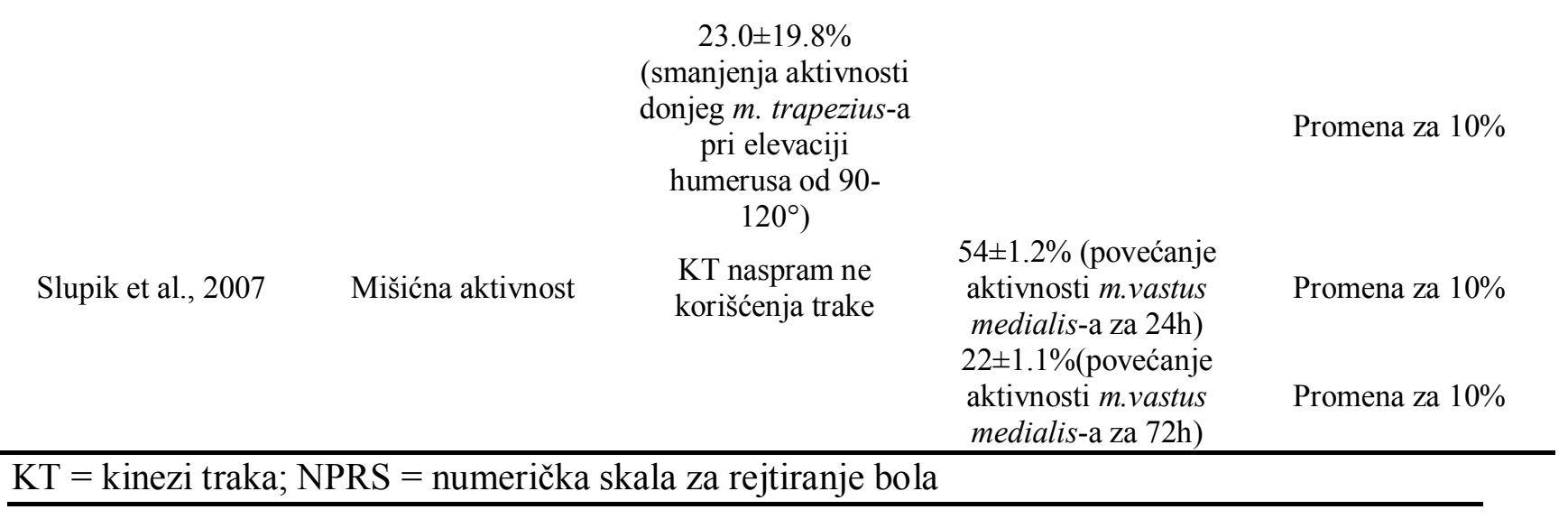

\section{DISKUSIJA}

Kinezi tejping je tehnika koja podrazumeva primenu elastične, lepljive trake na kožu. KT se pravi od elastičnog pamuka koji se može istegnuti od 120 do $140 \%$ od svoje prvobitne dužine. Koristi se za pritiskanje kože kako bi se uticalo na somatosenzorni sistem koji se nalazi pod uticajem trake (Kase i Wallis, 2002). U poređenju sa konvencionalnom trakom, predpostavlja se da KT pružaju veći opseg pokreta, kao i to da se mogu nositi duži vremenski period bez potrebe za ponovnim lepljenjem (Kase i Wallis, 2002). Navedeni korisni efekti KT uključuju poboljšanje pravilnog pozicioniranja mišića i zglobova tako što se jačaju oslabljeni mišići (Kase i Wallis, 2002), zatim poboljšanje cirkulacije krvi i limfe tako što povećava intersticijalni prostor između kože i potkožnog vezivnog tkiva - čime se povećava cirkulacija i venske i limfne tečnosti (Kase $\mathrm{i}$ Wallis, 2002), potom smanjenje bola, time što se smanjuje pritisak na nocioceptore, zatim repoziciju delimično izčašenih zglobova smanjenjem abnormalne mišićne tenzije pri čemu se olakšsava vraćanje funkcije fascije i mišića (Kase i Wallis, 2002), kao i povećanje propriocepcije putem stimulacije kutanih mehanoreceptora. Kinezi traka može da se primeni na bukvalno bilo koji mišić ili zglob na telu. Međutim, postoje minimalni dokazi o tome da se podrži upotreba ove trake u tretiranju mišićno koštanih poremećaja. Ograničene informacije o primeni KT nalažu da se KT mogu primeniti za poboljšanje funkcija ljudske lokomocije. Pored toga, KT pomažu u smanjenju bola, zatim u povećanju stabilnosti i propriocepcije kod pacijenata sa akutnom dislokacijom patele, zatim kodpacijenata koji su pretrpeli moždani udar, ali i u stanjima disfunkcije trupa.

Smatra se da KT olakšavaju bol tako što vrše stimulaciju senzitivnih nervnih puteva, tj. povećanjem aferentnih povratnih informacija. Predloženi mehanizam putem koga KT smanjuju bol zasniva se na redukciji aferentnih impulsa koji pristižu od nocioceptora. Pored toga, KT podižu kožu čime se smanjuje pritisak na mehanoreceptore kože.

Od 10 procenjenih istraživanja samo je studija (GonzáLez-Iglesias, Fernández-de-lasPeñas, Cleland, Huijbregts i Gutiérrez-Vega, 2009) zabeležila statistički značajne rezultate merenja bola. Oni su primetili značajno smanjenje bola na skali numeričke ocene (NPRS) u grupi sa KT naspram grupe pacijenata sa akutnim poremećajima koji su nastali naglim trzanjem i koja je prividno tretirana.

Jedan od predloženih mehanizama uticaja KT na aktivan opseg kretanja je povećanje cirkulacije krvi u predelu koji je obuhvaćen trakom; fiziološka promena koja olakšava opseg

Ilić, B., et al: Efikasnost kinezi traka...Sportlogia 2017, 13 (1), 53- 67. Stranica 59. 
pokreta unutar mišića. Dodatna teorija je da je strah od pokreta povezan sa intezitetom bola kod pacijenata, tako da primena KT obezbeđuje senzornu podršku koja smanjuje strah od pokreta, i time utiče na povećanje opsega istih (GonzáLez-Iglesias, Fernández-de-las-Peñas, Cleland, Huijbregts i Gutiérrez-Vega, 2009). Thelen, Dauber i Stoneman (2008) su procenili opseg bezbolne abdukcije kod pacijenata sa impidžmentom rotatorne manžetne, definišući klinički značajnu promenu sa $15^{\circ}$ povećanja. Nameće se zaključak iz ovih rezultata da KT imaju veoma mali, korisni kratkotrajni efekat na opseg kretanja određenih zglobova kod povređenih pacijenata. GonzáLez-Iglesias, Fernández-de-las-Peñas, Cleland, Huijbregts i Gutiérrez-Vega (2009) su procenili cervikalne pokrete u 6 pravaca odmah nakon tretmana i nakon $24 \mathrm{~h}$. Zaključak ove studije je da KT imaju beznačajan uticaj na cervikalni opseg pokreta za veliku većinu cervikalnih pokreta i akutno i 24 h nakon tretmana. Hsu, Chen, Lin, Wang i Shih (2009) su istraživali efekat KT na kinetiku ramena kod bejzbol igrača sa impidžement sindromom. KT grupa je imala statistički značajna poboljšanja kod skapularne orijentacije u poređenju sa placebo grupom zadnjeg nagiba na $30^{\circ}$ i $60^{\circ}$ humeralnog izdizanja, ali ni jedne druge mere skapularne orijentacije ili pomerenja nisu bile statistički značajne. Merenja na $30^{\circ}, 60^{\circ}$ i $90^{\circ}$ zadnjeg skapularnog nagiba su takođe potencijalno korisna u našoj analizi, iako su zabeležena kao statistički beznačajna od strane autora.

Ovo istraživanje je pronašlo beznačajne ili nejasne razlike za ostalih 19 merenja skapularne orijentacije. Nije se moglo zaključiti da je bilo korisnih dejstava za bilo koja od 24 skapularnih merenja, sa mogućim štetnim posledicama koje su pronađene kod 8 merenja. KT moguće da imaju korisno dejstvo na poboljšanje skapularne kinetike kod subjekata koji su imali iščašenje ramenog zgloba, ali samo za određen stepen humeralnog nagiba. Generalno, uticaj KT je beznačajan, čak moguće i štetan za određena merenja, i prema tome se ne preporučuje kao vid tretmana iščašenja ramenog zgloba.

Yoshida i Kahanov (2007) su procenili uticaj KT na fleksiju trupa, ekstenziju i bočnu fleksiju kod 30 zdravih pacijenata, korišćenjem slučajnog crossover dizajna. Bilo je pozitivnih promena za fleksiju trupa sa srednjim povećanjem od $17.8 \mathrm{~cm}$ u uslovima korišćenja KT. Međutim uticaj tejpiranja ne rešava problem, s obzirom da je poređenje vršeno u uslovima bez traka. Promene u ekstenziji donjeg trupa, kao i bočne fleksije su bile beznačajne, ali autori nisu zabeležili specifične $p$ vrednosti ili interval poverenja da bi mogli da donesu zaključak o veličini ovih rezultata. Uticaj KT na opseg kretanja ostaje nejasan zbog ograničenog broja istraživanja na različite zglobove, kao i suprotnosti rezultata. Korisni uticaji KT u visoko kvalitetnom istraživanju obavljenom od strane (Thelen, Dauber i Stonerman, 2008) pokazuju da KT imaju bar mali, koristan kratkoročni uticaj na opseg kretanja kod određenih zglobova povređenih subjekata. Korisni uticaji su zabeleženi kod cervikalne ekstenzije i desne bočne fleksije kod pacijenata sa akutnim poremećajima nastalim kao posledica naglog trzanja vrata, ali i za određene aspekte skapularne kinetike. Međutim, beznačajni i štetni uticaji koji se mogu zaključiti iz rezultata (GonzáLez-Iglesias, Fernández-de-las-Peñas, Cleland, Huijbregts i Gutiérrez-Vega, 2009) i (Hsu, Chen, Lin, Wang i Shih, 2009) sugerišu da je neophodna dalja klasifikacija. Osvrćući se na prethodno isnešene tvrdnje, mi ne bi smo predložili korišćenje KT u cilju poboljšanja opsega kretanja kod povređenih subjekata. Kod zdravih učesnika, zabeležen je jako mali pozitivan uticaj kod fleksije trupa, koji je izračunat iz rezultata istraživanja (Yoshida i Kahanov, 2007).

Međutim, s obzirom da nisu korišćene placebo trake, nepoznanica je da li ovo predstavlja korisnost KT u poređenju sa tradicionalnim korišćenjem traka. Neophodna su dodatna istraživanja da bi se utvrdio uticaj KT na merenja opsega kretanja.

Ilić, B., et al: Efikasnost kinezi traka...Sportlogia 2017, 13 (1), 53- 67. Stranica 60. 
Takođe, za KT se pretpostavlja da omogućavaju malo neposredno povećanje snage mišića proizvodeći koncentrično povlačenje fascije, što može da stimuliše povećanje kontrakcije mišića. KT mogu da povuku kožu ili mišićnu fasciju ispod kože čime se oslobađa zategnuta površina mišića i poboljšava fleksibilnost (Lee J-H., Yoo i Lee K-S., 2010). Pored toga, KT mogu poboljšati mišićnu aktivnost i mišićno poravnanje što može dovesti do marginalnog povećanja mišićne sile (Hsu, Chen, Lin, Wang i Shih, 2009).

Četiri od deset istraživanja su zabeležela pozitivne rezultate u merenju procene snage. (Lee J-H., Yoo i Lee K-S., 2010) su procenili uticaj KT na snagu stiska šake kod 40 zdravih subjekata. Snaga stiska šake je bila značajno viša i kod muškaraca i kod žena kada su KT bile korišćene na mišiće fleksore dominantne ruke u poređenju sa uslovima kada nisu korišćene trake. Oba rezultata su ocenjena da su verovatno korisna u našoj analizi, međutim, s obzirom da nisu postojali uslovi placebo tejpiranja, ove rezultate bi trebalo uzimati sa oprezom.

Vithoulka, Beneka, Malliou, Aggelousis, Karatsolis i Diamantopoulos (2010) su istraživali uticaj KT na obrtni moment kvadricepsa i zabeležili su statistički značajno povećanje u uslovima korišćenja KT za vreme ekscentrične procene. Međutim, značajne razlike su postojale u odnosu na one-way Anova rezultate poređenjem KT, placebo grupe sa trakama i bez traka. Međutim, studija (Briem, Eythörsdöttir, Magnúsdóttir, Pálmarsson, Rúnarsdöttir i Sveinsson, 2011) koja se bavila procenom efekata KT na nivo aktivacije $m$. fibularis longus-a tokom ,,iznenadne pertumbacije” skočnog zgloba kod 51 zdravog sportiste, nije našla znatne promene u mišićnoj sili. S druge strane, studija (Hsu, Chen, Lin, Wang i Shih, 2009) je pokazala da je aplikacija KT dovela do znatnog povećanja elektromiografske aktivacije donjeg $m$. trapezius-a tokom abdukcija ramena kod 17 sportista koji su patili od impidžment sindroma. Slični nalazi su prijavljeni i u studiji (Firth, Dingley, Davies, Lewis i Alexander, 2010) gde nisu pronađene promene u dužini skoka sa jedne noge iz mesta, ni kod zdravih sportista niti kod onih koji su patili od tandinopatije Ahilove tetive, nakon primene KT na skočni zglob. Studija (Hwang-Bo i Lee, 2011), koja je analizirala visinu vertikalnog skoka 30 min nakon aplikacije KT na skočni zglob kod zdravih subjekata, takođe nije dobila znatne promene. Što se tiče statičke ravnoteže, studija (Aytar, Ozunlu, Surenkok, Baltaci, Oztop i Karatas, 2011) je zabeležila poboljšanje tokom aplikacije KT na $m$. quadriceps kod žena sa petelofemoralnim sindromom. Pored toga, studija (Alano, Neto, Amorim, Macedo i Brasileiro, 2013) je pokazala da aplikacija KT na $m$. rectus femoris, $m$. vastus lateralis i $m$. vastus medialis ne može izmeniti funkcionisanje donjih ekstremiteta, statičku ravnotežu na jednoj nozi ni maksimalni obrtni moment ekstenzora kolena niti amplitudu aktivacije $m$. vastus lateralis-a kod zdravih žena. Štaviše, aplikacija neelastične lepljive trake na isto područje kože ne dovodi do bitnih promena ovih varijabli. Fu, Wong, Pei, Wu, Chou i Lin (2008) su istraživali uticaj KT na mišićnu snagu zdravih sportista studenata. Jedan statistički značajan rezultat je zabeležen za koncentričnu kontrakciju kvadricepsa na $180^{\circ} / \mathrm{sec} 12 \mathrm{~h}$ nakon aplikacije traka, dok su trake i dalje bile in situ. U suprotnosti sa ovim pozitivnim ishodima, (Chang, Chou, Lin, J., Lin, C. i Wang, 2010) nisu zabeležili statistički značajne razlike u maksimalnoj snazi stiska ruke koji su mereni u uslovima bez traka, sa placebo trakama i sa KT kod 21 zdravih sportista studenata. Postojao je jedan nejasan i osam beznačajnih rezultata merenja snage koji sprečava donošenje jasnog zaključka. Dalja istraživanja na sličnim mišićima, i posebno dugotrajan uticaj KT na jačanje snage zahetvaju ispitivanja. Postoje studije koje su zabeležile značajne efekte nakon aplikacije bele sportske trake na skočni zglob, na propriocepciju skočnog zgloba (Karlsson i Andreasson, 1992; Robbins, Waked i Rappel, 1995; Heit, Lephart i Rozzi, 1996; Simoneau, Degner, Kramper i Kittleson, 1997). Međutim, jako malo istraživanja je provedeno po pitanju efekata primene traka (kao što je

Ilić, B., et al: Efikasnost kinezi traka...Sportlogia 2017, 13 (1), 53- 67. Stranica 61. 
Kinesio $^{\text {TM }}$ traka) na povećanje osetljivosti kože. Studija (Murray i Husk, 2001) ispitala je efekte KT na propriocepciju skočnog zgloba. Oni su došli do zaključka da je primena KT, u stanju izčašenja leteralne strane skočnog zgloba, poboljšala propriocepciju, u položaju bez punog oslonca na noge, u srednjem položaju skočnog zgloba gde su mehanoreceptori ligamenata bili neaktivni. Istraživanje (Chang, Chou, Lin, J., Lin, C. i Wang, 2010) o snazi greške prilikom merenja jačine stiska kod 21 zdravih sportista studenataje zabeležilo dva pozitivna rezultata u pogledu propriocepcije. Halseth, McChesney, DeBeliso, Vaughn, i Lien (2004) su takođe istraživali uticaj KT na propriocepciju skočnog zgloba. KT grupa nije pokazala statistički značajnu promenu u apsolutnoj grešci za merenje reprodukcije pozicije skočnog zgloba prilikom fleksije i inverzije tabana, kada se poredi sa grupom koja nije koristila trake. Nije bilo dovoljno dostupnih podataka kako bi se mogao izvući precizan zaključak po pitanju ovih rezultata.

Kako bi se u potpunosti razumeo efekat KT na propriocepciju, potrebno je da se buduća istraživanja sprovedu na drugim zglobovima, kao i sa drugim metodama aplikacije Kinesio ${ }^{\mathrm{TM}}$ trake. Dalja istraživanja mogu dati informacije od vitalnog značaja o pozitivnim efektima primene Kinesio $^{\mathrm{TM}}$ trake tokom aktutnih i subakutnih faza rehabilitacije čime se ubrzava vreme vraćanja aktivnom učešću u aktivnostima.

Nejasno je u kom pravcu promena u mišićnoj aktivnosti predstavlja koristan uticaj; smanjenje može da podrazumeva da KT imaju podržavajući uticaj i da mišić ima veću efikasnost, dok povećanje može da predstavlja olakšavajući uticaj i povećanu mišićnu funkciju (Hsu, Chen, Lin, Wang i Shih, 2009). Ovo najverovatnije zavisi od procene konkretnog mišića, odabranih subjekata (zdravih ili povređenih), al i tehnike tejpiranja. Studija (Lin, Hung i Yang, 2011) je pokazala znatne promene u EMG aktivaciji akapularnih mišića tokom primene trake $u$ asimptomatskoj grupi. Proprioceptivna povratna informacija se takođe poboljšala nakon tejpiranja. Stoga, mehanizmi putem kojih se skapularno tejpiranje može objasniti tiču se neuromišićne kontrole i proprioceptivnih faktora povratnih informacija. Studija (Morin, Tiberio i Austin, 1997) je takođe našla znatno smanjenje mišićne aktivnosti u gornjem i donjem $m$. trapezius-u nakon tejpiranja. Studija (Slupik, Dwornik, Bialoszewski i Zych, 2007) je prijavila povećanje aktivnosti za $54 \%$ u $m$. vastus medialis-u 24 h nako aplikacije KT. Zaključeno je da bi ovaj efekat mogao biti veoma značajan. Nakon $72 \mathrm{~h}$ postojalo je srednje povećanje za $22 \%$, u poređenju sa početnim vrednostima. Promene mišićne aktivacije 10 minuta i 96 sati nakon aplikacije KT su bile beznačajne. Međutim, način na koji su ispitanici mereni u dva slučaja (sa i bez KT), nije bio izveden na odgovarajući crossover način te stoga rezultati nisu validni. S obzirom da nije bilo placebo grupe, nismo bili sigurni da li su dobijene promene bile izazvane primenom kinezi trake ili samo tejpiranjem. U studiji (GonzáLez-Iglesias, Fernández-de-lasPeñas, Cleland, Huijbregts i Gutiérrez-Vega, 2009), koja je istraživala uticaj KT na mišićnu aktivnost, KT su povezane sa značajnom promenom u mišićnoj aktivnosti oko specifičnog opsega dizanja humerusa. Međutim većina razlika je bila beznačajna ili nejasna. Dalja istraživanja su neopodna da bi se odredilo da li promene izazvane korišćenjem KT imaju pozitivan uticaj na tretman povreda. 


\section{ZAKLJUČAK}

Glavna svrha ovog sistematičnog pregleda je bila da se istraži efiksanost KT u tretmanu i rehabilitaciji mišićno-skeletnih povreda. Teorija iza upotrebe KT je ta da primena trake poboljšava limfnu i krvnu cirkulaciju, bez smanjenja opsega pokreta u zglobu, čime se smanjuje bol, inflamacija i vreme oporavka. Kinezi trake su primamljive aktivnim pacijentima i elitnim sportistima koji traže sredstva za poboljšanje performansi, funkcionisanja i sile, kao i za smanjenje bola nakon mišićno-skeletnih povreda.

Elektronske baze podataka, poput SPORTDiscus, Scopus,MEDLINE, ScienceDirect i sajtovi sportske medicine su pretraživani koristeći ključne reči 'kinezi tejping/trake'. Od ukupno 96 pregledanih članaka, deset studija je korišćeno za meta-analizu. Dve studije su ispitivale povrede u vezi sa sportom (GonzáLez-Iglesias, Fernández-de-las-Peñas, Cleland, Huijbregts i Gutiérrez-Vega, 2009; Hwang-Bo i Lee, 2011), dok se samo jedna bavila ispitivanjem povreda kod sportista (Hsu, Chen, Lin, Wang i Shih, 2009).

Studije su pokazale da se KT mogu koristiti u prevenciji i tretmanu mišićno-skeletnih povreda (GonzáLez-Iglesias, Fernández-de-las-Peñas, Cleland, Huijbregts i Gutiérrez-Vega, 2009; Hsu, Chen, Lin, Wang i Shih, 2009; Hwang-Bo i Lee, 2011; Kaya, Zinnuroglu i Tugcu, 2010; Lee, 2015; Mostafavifar, Wertz i Borchers, 2012; Thelen, Dauber i Stoneman, 2008). KT mogu imati skromne korisne efekte na silu, osećaj za grešku u primenjenoj sili i na aktivan opseg pokreta u povređenoj površini, međutim, potrebna su buduća razjašnjavanja (Williams, Whatman, Hume i Sheerin, 2012). Nije bilo značajnih dokaza koji bi podržali korišćenje KT za poboljšanje drugih mišićno-skeletnih stanja (bol, propriocepcija skočnog zgloba ili mišićna aktivnost) (Williams, Whatman, Hume i Sheerin, 2012).

Ovaj sistematski pregled nije pronašao dovoljno dokaza za ili protiv upotrebe KT u poboljšanju funkcionisanja i performansi nakon mišićno-skeletne povrede ili za smanjenje bola. Broj konzistentnih studija visokog kvaliteta je ograničen, te ova tema zahteva dalja istraživanja koja bi pružila dokaze visokog kvaliteta, zatim koja bi imala veći broj ispitanika, snažne rezultate i duži period praćenja kako bi se pokazala efikasnost ili neefikasnost KT, ali nameće se zaključak da su KT bezbedne i da mogu biti korisne za sportiste, uprkos manjku dokaza koji bi pokazali njihovu kliničku efikasnost u stanjima nakon mišićno-skeletnih povreda.

\section{LITERATURA}

Alano, C., Neto, F., Amorim, A., Macedo, L., \& Brasileiro, J. (2013). Kinesio taping does not alter neuromuscular performance of femoral quadriceps or lower function in healthy subjects: Randomized, blind, controlled, clinical trial. Manual Therapy, 18(1), 41-45. https://doi.org/10.1016/j.math.2012.06.009 PMid:22796389

Aytar, A., Ozunlu, N., Surenkok, G. Baltaci, G., Oztop, P., \& Karatas, M. (2011). Initial effects of kinesio taping in patients with patellofemoral pain syndrome: a randomized, double-blind study. Isokinetics and Exercise Science, 19(2), 135-142.

Briem, K., Eythörsdöttir, H., Magnúsdóttir, R. Pálmarsson, R., Rúnarsdöttir, T., \& Sveinsson, H. (2011). Effects of kinesio tape compared with nonelastic sports tape and the untaped ankle during a sudden inversion perturbation in male athletes. Journal Orthopaedic and Sports Physical Therapy, 41(5), 328-335.

https://doi.org/10.2519/jospt.2011.3501

PMid:21212501

Ilić, B., et al: Efikasnost kinezi traka...Sportlogia 2017, 13 (1), 53- 67. Stranica 63. 
Chang, H., Chou, K., Lin, J., Lin, C., \& Wang, C. (2010). Immediate effect of forearm Kinesio taping on maximal grip strength and force sense in healthy collegiate athletes. Physical Therapy in Sport, $11(4), 122-127$.

https://doi.org/10.1016/j.ptsp.2010.06.007

PMid:21055705

Firth, B., Dingley, P., Davies, E., Lewis, J., \& Alexander, C. (2010). The effect of kinesiotape on function, pain, and motoneuronal excitability in healthy people and people with achilles tendinopathy. Clinical Journal of Sport Medicine, 20(6), 416-421.

https://doi.org/10.1097/JSM.0b013e3181f479b0

PMid:21079436

Fu, T., Wong, A., Pei, Y., Wu, K., Chou, S., \& Lin, Y. (2008). Effect of Kinesio taping on muscle strength in athletes-A pilot study. Journal of Science and Medicine in Sport, 11(2), 198-201.

https://doi.org/10.1016/j.jsams.2007.02.011

PMid:17588814

GonzáLez-Iglesias, J., Fernández-de-las-Peñas, C., Cleland, J., Huijbregts, P., \& Gutiérrez-Vega, M. (2009). Short-Term Effects of Cervical Kinesio Taping on Pain and Cervical Range of Motion in Patients With Acute Whiplash Injury: A Randomized Clinical Trial. Journal of Orthopaedic \& Sports Physical Therapy, 39(7), 515-521.

https://doi.org/10.2519/jospt.2009.3072

PMid:19574662

Halseth, T., McChesney, J.W., DeBeliso, M., Vaughn, R., \& Lien, J. (2004). The effects of Kinesio taping on proprioception at the ankle. J Sports Sci \& Med, 3(1), 1-7.

PMid:24497814 PMCid:PMC3896108

Hammer, W. (2006): Functional Soft-tissue Examination and Treatment by Manual Methods (3rd ed.). Boston, USA: Jones and Bartlett Publishers.

Heit, E., Lephart, S., \& Rozzi, S. (1996). The effect of ankle bracing and taping on joint position sense in the stable ankle. Journal of Sport Rehabilitation, 5, 206-213. https://doi.org/10.1123/jsr.5.3.206

Hsu, Y., Chen, W., Lin, H., Wang, W., \& Shih, Y. (2009). The effects of taping on scapular kinematics and muscle performance in baseball players with shoulder impingement syndrome. Journal of Electromyography and Kinesiology, 19(6), 1092-1099.

https://doi.org/10.1016/j.jelekin.2008.11.003

PMid:19147374

Hwang-Bo, G. \& Lee, J. (2011). Effects of kinesio taping in a physical therapist with acute low back pain due to patient handling: A case report. International Journal of Occupational Medicine and Environmental Health, 24(3), 320-323.

https://doi.org/10.2478/s13382-011-0029-8

PMid:21845524

Jaraczewska, E. \& Long, C. (2006). Kinesio taping in stroke: improving functional use of the upper extremity in hemiplegia. Topics in Stroke rehabilitation, 13, 31-42.

https://doi.org/10.1310/33KA-XYE3-QWJB-WGT6

PMid:16987790

Kahanov, L. (2007). Kinesio taping, Part 1: An overview of its use in athletes. Athletic Therapy Today, $12,17-18$. https://doi.org/10.1123/att.12.3.17

Karlsson, J. \& Andreasson, G. (1992). The effect of external ankle support in chronic lateral ankle joint instability. An electromyographic study. Am J Sports Med., 20(3), 257-261.

https://doi.org/10.1177/036354659202000304

PMid:1636854

Kase, K., Hashimoto, T., \& Tomoki, O. (1996). Development of kinesio taping perfect manual. Kinesio Taping Association, 6(10), 117-118.

Ilić, B., et al: Efikasnost kinezi traka...Sportlogia 2017, 13 (1), 53- 67. Stranica 64. 
Kase, K., \& Wallis, J. (2002). The latest kinesio taping method. Tokyo, JPN: Ski-Journal.

Kase, K., Wallis, J., \& Kase, T. (2003). Clinical therapeutic applications of the Kinesio Taping method. Tokyo, JPN: Kinesio Taping Association.

Kaya, E., Zinnuroglu, M., \& Tugcu, I. (2010). Kinesio taping compared to physical therapz modalities for the treatment of shoulder impingement syndrome. Clinical Rheumatology, 30(2), 201-207. https://doi.org/10.1007/s10067-010-1475-6 PMid:20443039

Kinesio Holding Corporation (2008). Kinesio Taping Method Concepts. Retrived from http://kinesiotaping.com/kinesio-concept.php.

Kneeshaw, D. (2002). Shoulder taping in the clinical setting. Journal of Bodywork and Movement Therapies, 6, 2-8. https://doi.org/10.1054/jbmt.2001.0233

Lee, J.H., Yoo, W.G., \& Lee, K.S. (2010). Effects of head-neck rotation and Kinesio taping of the flexor muscles on dominanthand grip strength. J Phys Ther Sci, 22(3), 285-289. https://doi.org/10.1589/jpts.22.285

Lee, J. (2015). The Kinesio Taping technique may affect therapeutic results. Journal of Physiotherapy, 61(4), 231-232. https://doi.org/10.1016/j.jphys.2015.03.006 PMid:26093808

Lim, C., Park, Y., \& Bae, Y. (2013). The Effect of the Kinesio Taping and Spiral Taping on Menstrual Pain and Premenstrual Syndrome. Journal of Physical Therapy Science, 25(7), 761-764. https://doi.org/10.1589/jpts.25.761 PMid:24259847 PMCid:PMC3820414

Lin, J., Hung, C., \& Yang, P. (2011). The effects of scapular taping on electromyographic muscle activity and proprioception feedback in healthy shoulders. J Orthop Res, 29(1), 53-57. https://doi.org/10.1002/jor.21146 PMid:20607815

Lipinska, A., Sliwinski, Z., Kiebzak, W., Senderek, T., \& Kirenko, J. (2007). Influence of Kinesiotaping applications on lymphoedema of and upper limb in women after mastectomy. Polish Journal of Physiotherapy, 7, 258-269.

Liu, Y.H., Chen, S.M., Lin, C.Y., Huang, C.I., \& Sun, Y.N. (2007). Motion tracking on elbow tissue from ultrasonic image sequence for patients with lateral epicondylitis. Proceedings of the $29^{\text {th }}$ Annual International Conference of the IEEE EMBS Cité Internationale (pp. 95-98). Lyon, F. https://doi.org/10.1109/iembs.2007.4352231

Morin, G., Tiberio, D., \& Austin, G. (1997). The Effect of Upper Trapezius Taping on Electromyographic Activity in the Upper and Middle Trapezius Region. Human kinetics journal, 6(4), 309-318. https://doi.org/10.1123/jsr.6.4.309

Mostafavifar, M., Wertz, J., \& Borchers, J. (2012). A Systematic Review of the Effectiveness of Kinesio Taping for Musculoskeletal Injury. The Physician and Sportsmedicine, 40(4), 33-40. https://doi.org/10.3810/psm.2012.11.1986 PMid:23306413

Murray, H., \& Husk, L. J. (2001). Effect of Kinesio Taping on proprioception in the ankle. The Journal of Orthopaedic and Sports Physical Therapy, 31-37.

Nosaka, K. (1999). The Effect of Kinesio Taping on Muscular MicroDamage Following Eccentric Exercises. Paper presented at the 15th Annual Kinesio Taping International Symposium Review. (pp. 70-73). Tokyo, JPN. Kinesio Taping Association.

Riemann, B. L., \& Lephart, S. M. (2002). The sensorimotor system, part I: the physiologic basis of functional joint stability. Journal of Athletic Training, 37, 71-79. PMid:16558670 PMCid:PMC164311

Robbins, S., Waked, E., Rappel, R. (1995). Ankle taping improves proprioception before and after exercise in young men. Br. J. Sports Med., 29(4), 242-247.

Ilić, B., et al: Efikasnost kinezi traka...Sportlogia 2017, 13 (1), 53- 67. Stranica 65. 
https://doi.org/10.1136/bjsm.29.4.242

PMid:8808537 PMCid:PMC1332234

Simoneau, G. G., Degner, R. M., Kramper, C. A., \& Kittleson, K. H. (1997). Changes in ankle joint proprioception resulting from strips of athletic tape applied over the skin. Journal of Athletic Training,32, 141-147. PMid:16558444 PMCid:PMC1319817

Slupik, A., Dwornik, M., Bialoszewski, D., \& Zych, E. (2007). Preliminary report. Ortop Traumatol Rehabil., 9(6), 644-651. PMid:18227756

Thelen, M.D., Dauber, J.A., \& Stoneman, P.D. (2008). The clinical efficacy of kinesio tape for shoulder pain: a randomized, doubleblinded, clinical trial. J Orthop Sports Phys Ther.,38(7), 389-395. https://doi.org/10.2519/jospt.2008.2791 PMid:18591761

Vithoulka, I., Beneka, A., Malliou, P., Aggelousis, N., Karatsolis, K., \& Diamantopoulos, K. (2010). The effects of Kinesio-Taping on quadriceps strength during isokinetic exercise in healthy non athlete women. Isokinetics and Exercise Science,18(1), 1-6.

Williams, S., Whatman, C., Hume, P., \& Sheerin, K. (2012). Kinesio Taping in Treatment and Prevention of Sports Injuries. Sports Medicine, 42(2), 153-164.

https://doi.org/10.2165/11594960-000000000-00000 PMid:22124445

Winter, J. A., Allen, T. J., \& Proske, U. (2005). Muscle spindle signals with the sense of effort to indicate limb position. Journal of Physiology, 568, 1035-1046.

https://doi.org/10.1113/jphysiol.2005.092619 PMid:16109730 PMCid:PMC1464181

Yoshida, A., \& Kahanov, L. (2007). The Effect of Kinesio Taping on Lower Trunk Range of Motions. Research in Sports Medicine, 15(2), 103-112. https://doi.org/10.1080/15438620701405206 PMid:17578750

Zajt-Kwiatkowska, J., Rajkowska-Labon, E., Skrobot, W., Bakula, S., \& Szamotulska J (2007). Application of Kinesio taping for treatment of sports injuries. Medical Sports Press, 113, 130-134. 


\section{SUMMARY}

Kinesio Tape is becoming more widely used in sports physiotherapy and for postural rehabilitation. Many professional athletes use the tape to support injured, fatigued, or overused muscles. The tape's construction is unique, featuring a highly elastic property that engages both the muscles and fascia. It is claimed that KT supports injured muscles and joints and helps relieve pain by lifting the skin and allowing improved blood and lymph flow. The aim of this review was to evaluate, using meta-analysis, the effectiveness of $K T$ in the treatment and prevention of sports injuries. Electronic databases including SPORTDiscus, Scopus,MEDLINE, ScienceDirect and sports medicine websites were searched using keywords 'kinesio taping/tape'. The efficacy of KT in pain relief was trivial given there were no clinically important results. There were inconsistent ranges of motion outcome results, with at least small beneficial results seen in two studies, but trivial results in two other studies across numerous joint measurements. There was a likely beneficial effect for proprioception regarding grip force sense error, but no positive outcome for ankle proprioception. KT had some substantial effects on muscle activity, but it was unclear whether these changes were beneficial or harmful. In conclusion, there was little quality evidence to support the use of KT over other types of elastic taping in the management or prevention of sports injuries. KT may have a small beneficial role in improving strength, range of motion in certain injured subjects and force sense error compared with other tapes, but further studies are needed to confirm these findings.

Key words: sport medicine, kinesitherapy, recovery, atrophy 